\title{
Daya Dukung Perairan Untuk Budidaya Udang Vannamei Sistim Semi Intensif Dalam Pemanfaatan Wilayah Pesisir Kabupaten Pemalang
}

[Suitability Assessment of Land And Water Resources Support System for Raising Vannamei Semi Intensive Shrimp in Order To Use of Coastal Areas Pemalang Regency]

\author{
Pigoselpi Anas ${ }^{\bowtie}$, Dinno Sudinno, Iis Jubaedah \\ Sekolah Tinggi Perikanan, Jurusan Penyuluhan Perikanan \\ Jalan Cikaret Nomor 1 Bogor 16001, Jawa Barat
}

Diterima: 10 Juni 2015; Disetujui: 1 Desember 2015

\begin{abstract}
Abstrak
Kajian kesesuaian lahan dan daya dukung perairan untuk budidaya udang vannamei sistem semi intensif dalam rangka pemanfaatan wilayah pesisir Kabupaten Pemalang Provinsi Jawa Tengah telah dilakukanpada bulan Agustus - Oktober 2014 di kabupaten Pemalang yang merupakan salah satu daerah pendukung perikanan di Pantai Utara Jawa, yang memiliki perairan potensi untuk daerah budidaya udang. Tujuan penelitian ini adalah mengkaji kesesuaian lahan dan daya dukung kawasan pesisir untuk pengembangan budidaya udang Vanammei di wilayah pesisir Kabupaten Pemalang.Penelitian inimerupakan penelitian kualitatif dengan pendekatan berdasarkan studi kasus yaitu pemanfaatan lahan di wilayah pesisir Kabupaten Pemalang untuk kegiatan budidaya udang, Analisa Data terdiri dari analisis kesesuaian lahan dan analisis daya dukung kawasam pesisir. Hasil penelitian menunjukan bahwa berdasarkan perhitungan kesesuaian lahan, nilai total kategori kesesuaian lahan pesisir Kabupaten Pemalang adalah 448 dengan kategori Sesuai (S2) untuk pertambakan, sedangkan hasil penghitungan daya dukung kawasan pesisir, luas tambak untuk budidaya udang semi intensif yang dapat digunakan diwilayah pesisir Kabupaten Pemalang seluas 129,6 Ha dengan total produksi maksimum sebanyak 259,2 ton / MT.
\end{abstract}

Kata Kunci: Kesesuaian Lahan, daya dukung, udang vannamei

\begin{abstract}
Assessment of land suitability and carrying water for shrimp cultivation VANNAMEI system semiintensive in order to utilize the coastal areas of Pemalang in Central Java Province has been carried out in August-October 2014 Pemalang district which is one of the supporters of the fishery on the North Coast of Java, which has waters the potential for shrimp farming areas. The purpose of this study was Assessing the suitability of land and the carrying capacity of the coastal areas to the development of shrimp farming in coastal areas Vanammei Pemalang. This study is a qualitative research approach is based on case studies of land use in coastal areas Pemalang district for shrimp farming activities, Data Analysis consists of land suitability analysis and capacity analysis kawasam coast. The results showed that based on the calculation of land suitability, the total value of the category of land suitability coast of Pemalang are 448 categories Suitable (S2) for aquaculture, while the count result the carrying capacity of coastal areas, spacious ponds for shrimp cultivation semi-intensive to be used in the region of coastal Pemalang total area of 129.6 hectares with a maximum production of 259.2 tons / MT.
\end{abstract}

Keywords : Land suitability, carrying capacity, vannamei shrimp.

$\triangle$ Penulis korespondensi

Alamat surel:pigoselfianas@yahoo.com 
Daya Dukung Perairan Untuk Budidaya Udang Vannamei Sistim Semi Intensif dalam Pemanfaatan Wilayah Pesisir Kabupaten Pemalang

\section{PENDAHULUAN}

Salah satu permasalahan utama yang dihadapi dalam rangka pemanfaatan lahan pesisir di kabupaten Pemalang untuk kegiatan budidaya udang adalah adanya serangan penyakit yang disebabkan oleh penurunan kualitas lingkungan. Menurunnya kualitas lingkungan ini disebabkan baik oleh factor pemanfaatan sumberdaya yang berlebih dan cara pengelolaan yang tidak berkelanjutan maupun oleh adanya factor buangan limbah air budidaya selama operasional yang mengandung konsentrasi tinggi dari limbah organic dan nutrient sebagai konsekwensi dari masukkan aqua input dalam budidaya udang yang menghasilkan sisa pakan dan faeces yang terlarut ke dalam air untuk kemudian dibuang ke perairan sekitarnya. Perubahan ekologis lingkungan tambak akan mempengaruhi daya dukung lingkungan yang pada akhirnya mempengaruhi produksi tambak. Daya dukung lingkungan bagi tambak adalah suatu kemampuan alam untuk menyediakan keberadaan tambak yang dapat ditolerir (Barg, 1992 dalam fredinan 2008).

Kawasan tambak industrialisasi budidaya udang di suatu daerah tentunya memiliki karakteristik sumberdaya alam yang berbeda dengan daerah lain. Pengelolaan tambak harus dilakukan berdasarkan kaidah ramah lingkungan yaitu dengan pendekatan keterpaduan dan keseimbangan ekologis antara ekosistem kawasan pesisir dengan perairan di sekitarnya serta peningkatan produksi dilakukan dengan merevitalisasi tambak. Utojo et al 2014.

Salah satu komuditas unggulan dalam mendukung Industrialisasi perikanan budidaya adalah udang vannamei, karena memiliki nilai ekonomis tinggi (high economic value), permintaan pasar yang juga tinggi (high demand product), komoditas ini bahkan sampai saat ini merupakan primadona ekspor produk perikanan budidaya. Produksi udang Indonesia pada 3 tahun terakhir terus menunjukkan peningkatan cukup signifikan. Tercatat produksi tahun 2012 mengalam peningkatan hingga $32,87 \%$, dari 400.385 ton pada tahun 2011 menjadi 457.600 ton pada tahun 2012 (KKP, 2012 dalam Ichsan et al 2013).

Upaya yang dilakukan oleh pemerintah Kabupaten Pemalang dalam menggairahkan kembali usaha tambak udang yaitu mengembangkan budidaya udang introduksi yaitu udang Vanammei. Pola pengembangan Tambak udang di masa yang akan datang harus dilakukan secara berkelanjutan serta berpedoman pada aspek kesesuaian lahan dan daya dukung kawasan pesisir. Menurut Ahmad et al. (1996) pengembangan usaha budidaya perikanan pesisir berbasis budidaya laut dapat dilakukan pada kawasan pesisir seperti selat, teluk, laguna, dan muara sungai yang terlindung dari, pengaruh arus yang kuat, gelombang yang besar angin yang kencang serta bebas cemaran. Menurut Dahuri (2002) daya dukung disebut ultimate constraint yang diperhadapkan pada biota dengan adanya keterbatasan lingkungan seperti, ketersediaan makanan, ruang atau tempat berpijak, penyakit, siklus predator, oksigen, temperatur, atau cahaya matahari

Tujuan penelitian ini adalah :

- Mengkaji kesesuaian lahan untuk pengembangan budidaya udang Vanammeidi wilayah pesisir Kabupaten Pemalang

- Mengkaji daya dukung kawasan pesisir untuk pengembangan budidaya udangvanammei di wilayah pesisir Kabupaten Pemalang 
Pigoselpi Anas, Dinno Sudinno, Iis Jubaedah

\section{METODOLOGI PENELITIAN}

Penelitian dilakukan pada bulan Agustus - Oktober 2014 di kabupaten Pemalang yang merupakan salah satu daerah pendukung perikanan di Pantai Utara Jawa, yang memiliki perairan potensi untuk daerah budidaya udang. Lokasi penelitian ini adalah wilayah pesisir pada 4 kecamatan yaitu
Kecamatan Pemalang, Kecamatan

Taman, Kecamatan Petarukan dan Kecamatan Ulujami.

\section{Metode Penelitian}

Penelitian inimerupakan penelitian kualitatif dengan pendekatan berdasarkan studi kasus yaitu pemanfaatan lahan di wilayah pesisir Kabupaten Pemalang untuk kegiatan

Tabel 1. Penilaian Kesesuaian Lahan Untuk Tambak

\begin{tabular}{|c|c|c|c|c|c|}
\hline No & Parameter & Bobot & Nilai Batas & Skor & Nilai Akhir \\
\hline 1 & Salinitas $(\% 0)$ & 10 & $\begin{array}{l}\text { e15 atau }>40 \\
\quad 15-25 \\
>25-35 \\
>35-40\end{array}$ & $\begin{array}{c}4 \\
10 \\
8 \\
6\end{array}$ & \\
\hline 2 & $\begin{array}{l}\text { Amplitude Pasang } \\
\text { Surut (meter) }\end{array}$ & 10 & $\begin{array}{c}<0,8 \text { atau }>2,9 \\
1,1-1,5 \text { atau } 2,1-2,5 \\
>1,5-2,1 \\
0,8-1,1 \text { atau } 2,5-2,9\end{array}$ & $\begin{array}{c}4 \\
8 \\
10 \\
6\end{array}$ & \\
\hline 3 & $\begin{array}{l}\text { Bentuk Wilayah } \\
\text { (kemiringanlahan) }\end{array}$ & 8 & $\begin{array}{l}>0-2 \% \\
>2-3 \% \\
>3-5 \% \\
>5 \%\end{array}$ & $\begin{array}{c}10 \\
8 \\
6 \\
4\end{array}$ & \\
\hline 4 & $\begin{array}{l}\text { Tekstur Tanah } \\
\text { (Material dasar } \\
\text { perairan) }\end{array}$ & 8 & $\begin{array}{l}\text { Liat berpasir/liat } \\
\text { iempung berpasir } \\
\text { Lempung berpasir } \\
\text { Pasir berlumpur } \\
\text { Pasir berlempung } \\
\text { Lempung berdebu } \\
\text { lumpur }\end{array}$ & $\begin{array}{l}10 \\
8 \\
6 \\
4\end{array}$ & \\
\hline 5 & $\begin{array}{l}\text { Ketersediaan air tawar } \\
(\mathrm{km})\end{array}$ & 6 & $\begin{aligned} & <0,5 \\
> & 0,5-1 \\
> & 1-2,0 \\
& >2\end{aligned}$ & $\begin{array}{c}10 \\
8 \\
6 \\
4\end{array}$ & \\
\hline 6 & Fisiografil Wilayah & 6 & $\begin{array}{l}\text { Dataran pasang surut } \\
\text { - Delta pasang surut } \\
\text {-Rawa belakang } \\
\text { sungai } \\
\text { - Perbukitan }\end{array}$ & $\begin{array}{l}10 \\
8 \\
6 \\
4\end{array}$ & \\
\hline 7 & Jenis vegetasi & 6 & $\begin{array}{c}\text { - Rhizopora } \\
\text { Rhizopora } \\
\text { Bruguiera } \\
\text { Sonneratia, } \\
\text { Avicennia } \\
\text { - Bruguiera } \\
\text {-Nypa dan pandan }\end{array}$ & $\begin{array}{c}10 \\
8\end{array}$ & \\
\hline
\end{tabular}

Sumber: Modifikasi dari Pusat Penelitian dan Pengembangan Perikanan (1992) dan Poemomo (1992) 
budidaya udang. Studi kasus adalah studi mikro yang menyorot satu atau beberapa kasus dengan menggunakan strategi pengumpulan data yang bersifat multi metode yang pada umumnya memadukan metode pengamatan, wawancara dan analisis dokumen.

\section{Metode Pengumpulan Data}

Data yang digunakan dalam penelitian ini adalah data primer dan data skunder. Data primer adalah data yang diperoleh melalui survei langsung di lapangan yaitu kondisi biofisik lingkungan pesisir Kabupaten Pemalang. Sedangkan data sekunder diperoleh melalui kajian terhadap laporan-laporan hasil penelitian, publikasi ilmiah, peraturan perundang-undangan dan publikasi daerah. Data tersebut berasal dari instansi pemerintah maupun swasta yang mempunyai relevansi dengan tujuan penelitian.

\section{Metode Analisis Data}

Untuk menentukan kesesuaian lahan untuk kegiatan kelautan, perikanan, dan wisata alam beberapa parameter yang diukur adalah : jarak dari pantai, kedalamam pantai, kecepatan arus, kecerahan air laut, suhu, kondisi gelombang, salinitas, ketersediaan benih, kualitas air laut, dan sebagainya. Penentuan sesuai atau tidaknya suatu lahan dilakukan dengan cara pembobotan terhadap masing-masing parameter dan dibandingkan dengan standar yang telah ditentukan ( Senoaji 2009)

Penilaian kesesuaian lahan yang digunakan berdasarkan kriteria kesesuian lahanpetunjuk teknis Pusat Penelitian dan Pengembangan Perikanan (1992) dan Poernomo(1992). Kesesuaian lahan tersebut dibagi menjadi empat kelas, yaitu :

1. Kelas Sangat Sesuai (S1), yaitu : Lahan atau kawasan yang sesuai untuk tambak udang tanpa adanya faktor pembatas yang berarti, atau memiliki faktor pembatas yang bersifat minor dan tidak akan menurunkan produktivitasnya secara nyata.

2. Kelas Sesuai (S2), yaitu : Lahan atau kawasan yang mempunyai faktor pembatas yang berpengaruh terhadap produktivitas tambak udang, Di dalam pengelolaannya diperlukan tambahan masukan (input) teknologi dan tingkatan perlakuan.

3. Kelas Kurang Sesuai (S3), yaitu :Lahan atau kawasan yang kurang Sesuai diusahakan untuk tambak udang karena rnempunyai faktor pembatas yang berat dan bersifat tidal( permanen.

4. Kelas Tidak Sesuai (N), yaitu :Lahan yang mempunyai faktor pembatas cukup 
berat sehingga mencegah kemungkinan penggunaannya.

Untuk melakukan penilaian kesesuaian lahan suatu kawasan untuk pertambakan,masing - masing parameter kesesuaian lahan diberi bobot dan masing- masing diberinilai . Nilai ,akhir suatu parameter merupakau perkalian dari bobot dan nilai. Kemudiannilai seiuruh parameter dijumlahkan sehingga mendapatkan rrilai total dari kawasantersebut. Dari nilai total tersebut dilihat kualifikasi kesesuaian lahan dengan nilaikualiiikasi sebagai berikut: S1 (sangat sesuai): 459 - 540 ; S2 (sesuai): 377 - 458 ; S3(cukup sesuai) : $295 \sim 376$; N (tidak sesuai) $:<259$.

Menurut Dennis et al. (2004), aspek penting dalam kriteria penilaian kesesuaian lahan tambak yaitu topografi, lahan, hidrologi, iklim, dan vegetasi. Evaluasi lahan adalah proses penilaian atau keragaman (performance) lahan jika dipergunakan untuk tujuan tertentu, meliputi pelaksanaan dan interprestasi survey dan studi bentuk lahan, tanah, vegetasi, iklim dan aspek lahan lainnya, agar dapat mengidentifikasi, dan membuat perbandingan penggunaan lahan yang mukin dikembangkan (FAO, 1976 dalam Ristiyani 2012).

\section{Analisis Daya Dukuug Kawasan Pesisir} Analisis ini digunakan untuk mengetahui daya dukung kawasan pesisir yangterdapat dilokasi penelitian umtuk pengembangan kegiatan budidaya udang semi intensif Dalam rnenentukan daya

Tabel 2. Parameter dan Cara Analisis Kualitas Air Dalam Penelitian

\begin{tabular}{|c|c|c|c|c|}
\hline No & Parameter & Satuan & Alat/Cara Analisis & Keterangan \\
\hline A. & Fisika & & & \\
\hline 1. & Kecerahan & $\mathrm{cm}$ & Secchi disk & In situ \\
\hline 2. & Suhu & ${ }^{\circ} \mathrm{C}$ & Thermometer & In situ \\
\hline 3. & (TSS) & $\mathrm{mg} / 1$ & Gravimetri & Laboratorium \\
\hline B. & Kimia & & & \\
\hline 4. & $\mathrm{pH}$ & - & $\mathrm{pH}$ meter & In situ \\
\hline 5. & Salinitas & $\%$ & Refraktometer & In situ \\
\hline 6. & Oksigen terlarut & $\mathrm{Mg} / 1$ & DO meter & In situ \\
\hline 7. & BOD & $\mathrm{mg} / 1$ & Botol sampel; Titrimetrik & Laboratorium \\
\hline 8. & COD & $\mathrm{mg} / 1$ & Botol sampel; Titrimetrik & Laboratorium \\
\hline 9 & Ammonia & $\mathrm{mg} / 1$ & SNI. 06-6989-30-2005 & Laboratorium \\
\hline 10 & Phospat & $\mathrm{mg} / 1$ & APHA $4500-\mathrm{PO}_{4}-2005$ & Laboratorium \\
\hline 11 & $\mathrm{NO}_{3}$ & $\mathrm{mg} / 1$ & JIS. NO. K0102.43.2.4 & Laboratorium \\
\hline
\end{tabular}


dukung kawasan pesisir untuk pengembangan tambak dilakukan analisis kualitas air dan kuantitas perairan

Secara keseluruhan cara pengamatan kualitas air yang dilakukan dapat dilihat pada Tabel 2 .

\section{Analisis Kuantitas Perairan}

Pendekatan yang digunakan dalam analisis ini adalah pendekatan berdasarkan produksi udang maksimal yang dapat diperoleh dan kemampuan lingkungan perairan pesisir dalam menerima limbah kegiatan budidaya udang teknologi intensif. Sebagaidasar perhitungannya adalah volume air yang tersedia atau ketersediaan air perairanpesisir berdasarkan dari volume air laut yang masuk ke kawasan pesisir (Widigdo dan Pariwono 2003). Data yang diperoleh berdasarkan hasil pengukuran langsung dilapangan, maupun yang diperoleh dari berbagai sumber. Data tersebut meliputi :

1. Amplitudo atau kisaran pasang surut (tidal range) (h), yang diperoleh dari daftar pasang Surut yang dikeluarkan oleh Dishidros Angkatan Laut (data sekunder)

2. Panjang garis pantai (y), diperoleh dari Badan Perencanaan dan Pembangunan Kabupaten Pemalang, 2014)
3. Jarak dari garis pantai dengan lokasi yang kedalaman aimya kurang lebih 1 meter pada surut terendah (X) (hasil pengukuran lapangan)

4. Sudut kemiringan dasar laut kawasan pantai (0), diperoleh dari Peta Kemampuan Tanah yang dikeluarkan oleh BPN Kabupaten Pemalang

Setelah semua data terkumpul kemudian dilakukan analisis daya dukung kawasan pesisir dengan langkah $\sim$ langkah sebagai berikut :

a. Menghitung pasokan atau volume air laut yang masuk ke perairan pantai atau air yangtersedia dengan rumus $V_{0}=0,5$ hy [2x-h/tg $\theta$ ]

Dimana :

Vo $=$ Volume air laut yang masuk keperairan pantai

$\mathrm{h}=$ Kisaran pasut (tidal range) setempat

$\mathrm{x}=$ Jarak dari garis pantai (pada waktu pasang hingga lokasi intake air laut untuk keperluan tambak) $\mathrm{y}=$ Lebar areal tambak yang sejajar garis pantai

$\operatorname{tg} \theta=$ Sudut kemiringan dasar laut

b. Menghitung kapasitas limbah yang maksimal bisa diterima berdasarkan asumsi dari Alison 1981 dalam Widigdo \& Soewardi2002, dimana jumlah rnaksimal limbah dari tambak intensif yang bisa diasimilasi oleh lingkungan perairan secara alami adalah 0,01 dari 
volume air tersedia. Volume air yang masuk keperairan pantai tersebut (Vo) adalah volume air dalam satukali pasang. Jika tipe pasang surut semi diurnal atau ganda, dimana terjadi dua kalipasang dan dua kali Surut dalam sehali (24 jam), maka volume air yang masukkeperairan pantai adalah 2 kali Vo. Jumlah badan air penerima limbah (volume airyang masuk keperairan pantai) adalah 100 kali limbah tambak maksimal yang dibuangkeperairan pantai.Jika limbah cair maksimum tambak yang dibuang keperairan umumsebesar $10 \%$ dari total volume air tambak, maka volume air tambak maksimum $=10 \%$ volume air perairan umum (air yang masuk keperairan pantai), volume ini disebutair tersedia untuk tambak. Jika kedalaman air rata - rata 1 meter, dan pergantian airharian rata - rata $10 \%$ dari volume tambak, maka kebutuhan air tambak 1 ha per hari= $10.000 \mathrm{~m} 2 \times 0,1 \times 1 \mathrm{~m}=$ $1.000 \mathrm{~m} 3$. Luas tambak (ha) yang dapat dibangun adalahvolume air tersedia untuk tambak dibagi $10.000 \mathrm{~m} 3$.

c. Menghitung produksi maksimum dapat diperoleh berdasarkan asumsi dari Prasita dkk (2008) bahwa Produksi tambak berdasarkan tingkat teknologi budidaya yangdigunakan, dapat dihitung dimana untuk teknologi intensif target produksinya 7 ton/ha/MT, semiintensif 2
ton/ha/MT dan tradisional $500-700$ $\mathrm{kg} / \mathrm{ha} / \mathrm{MT}$.

\section{HASIL DAN PEMBAHASAN}

\section{Kondisi Umum Wilayah}

Kabupaten Pemalang secara geografis terletak diantara $6^{\circ} 46^{\prime} 52,20^{\prime \prime}$ $7^{\circ} 14^{\prime} 40,86^{\prime \prime}$ Lintang selatan dan $109^{\circ}$ $17^{\prime} 9^{\prime \prime}$ - $109^{\circ} 35^{\prime}$ 51,67" Bujur timur dengan luas wilayah 111.530,553 Ha. Dengan batas-batas administrasi Kabupaten Pemalang adalah sebagai berikut : - Sebelah utara berbatasan dengan Laut Jawa, Sebelah Timur berbatasan dengan Kabupaten Pekalongan, Sebelah Selatan berbatasan dengan Kabupaten Purbalingga, Sebelah Barat berbatasan dengan Kabupaten Tegal.

Kabupaten Pemalang yang mempunyai luas wilayah 111.530 .533 Ha Bapeda Pemalang 2013 dan memiliki panjang garis pantai $35 \mathrm{Km}$, yang sebagian besar digunakan sebagai areal pertambakan ( 1728,31 Ha ) (Dinas kelautan dan perikanan Kabupaten Pemalang 2013) yang tersebar pada empat kecamatan yaitu : Kecamatan Ulujami, Petarukan, Taman Dan Pemalang.

Keberadaan usaha pertambakan tersebut merupakan suatu modal pemban gunan yang penting bagi peningkatan 
penerimaan daerah. Budidaya sektor perikanan yang cukup intensif dikembangkan terutama terkonsentrasi di desa-desa pesisir Kecamatan Ulujami, merupakan sentra budidaya perikanan tambak (udang dan bandeng). Sekitar 90\% dari lahan tambak yang ada di Kabupaten Pemalang berada di kecamatan ini Seperti yang terdapat pada tabel 3 .

Untuk perkembangan produksi tambak untuk jenis komoditi udang Vannamei di Kabupaten Pemalang tahun 2010 - 2013 dapat dilihat pada tabel 4.

\section{Analisis Kesesuaian Lahan}

Kesesuaian lahan untuk pertambakan dalam hal ini berdasarkan kriteria yang diadopsi dari pusat penelitian perikanan (1992) dan Poernomo (1992) .

Berdasarkan tabel diatas, maka lahan pesisir Kabupaten Pemalang termasuk lahan dengan kategori Sesuai

(S2) untuk pertambakan.Analisis kesesuaian kawasan tambak dimaksudkan untuk mengetahui kesesuaian lahan dan perairan pesisir (fisik, kimia, dan biologi) peruntukan budidaya tambak, dilakukan dengan mengukur beberapa parameter lingkungan yang menjadi persyaratan ekologisbagi pengembangan pertambakan, yaitu fisik substrat, kualitas air, dan hidrooseanografi (Fredinan 2008). Kondisi lingkungan perairan merupakan faktor pembatas untuk penentuan kesesuaian lahan budidaya (Arifin dkk.2011)

\section{Kualitas Perairan}

Air sebagai media tempat hidup udang yang dipelihara ha rus memenuhi persyaratan kualitas dan kuantitas. Kualitas air merupakan salah satu faktor penentu dalam keberhasilan budidaya

Tabel 3. Data Luasan Tambak Eksisting Kabupaten Pemalang

\begin{tabular}{|c|c|c|c|c|c|c|c|c|c|}
\hline \multirow{3}{*}{ NO } & \multirow{3}{*}{$\begin{array}{c}\text { NAMA } \\
\text { KECAMATAN }\end{array}$} & \multirow{3}{*}{$\begin{array}{c}\text { LUAS } \\
\text { TOTAL } \\
(\mathrm{Ha})\end{array}$} & \multicolumn{6}{|c|}{ LUAS BERDASARKAN JENIS BUDIDAYA } & \multirow{3}{*}{ KOMODITAS UTAMA } \\
\hline & & & \multicolumn{2}{|c|}{ INTENSIF } & \multicolumn{2}{|c|}{ SEMI INTENSIF } & \multicolumn{2}{|c|}{ TRADISIONAL } & \\
\hline & & & $\mathrm{Ha}$ & $\%$ & $\mathrm{Ha}$ & $\%$ & $\mathrm{Ha}$ & $\%$ & \\
\hline 1 & PEMALANG & 49,90 & & & & & 49,90 & 100,00 & Bandeng \\
\hline 2 & TAMAN & 54,98 & & & 5,60 & 10,19 & 49,38 & 89,81 & Bandeng \\
\hline 3 & PETARUKAN & 89,23 & & & 16,00 & 17,93 & 73,32 & 82,17 & Bandeng, \& Rumput Laut \\
\hline 4 & ULUJAMI & 1534,20 & 63,25 & 4,12 & 1430,00 & 93,21 & 167,45 & 10,91 & $\begin{array}{c}\text { Bandeng, U. Vanamei, R. Laut, Kepiting } \\
\text { Soka, Kepiting Karamba }\end{array}$ \\
\hline \multicolumn{2}{|r|}{ LUAS TOTAL } & 1728,31 & 63,25 & 3,66 & 1451,60 & 83,99 & 340,05 & 19,68 & \\
\hline
\end{tabular}


udang.Beberapa parameter utama kualitas air yang dapat mendukung usaha budidaya udang adalah salinitas, $\mathrm{pH}$, suhu, kecerahan, oksigen terlarut dan padatan tersuspensi (PKSPL, 2002).Pengaruh dari parameterparameter ini untuk pertumbuhan udang oleh PKSPL (2002), antara lain dapat dijelaskan sebagai berikut:

\section{Parameter Fisika}

Kecerahan

$$
\text { Kecerahan (transparency) }
$$

menunjukkan seberapa jernih air disuatu perairan. Sehingga kecerahan dapat mencerminkan jumlah plankton disuatu perairan. Kecerahan adalah gambaran kedalaman air yang dapat ditembus oleh cahaya matahari dan dapat dilihat oleh mata pada umumnya. Kecerahan air ditentukan oleh partikel-partikel tersuspensi seperti tanah liat, bahan organik dan mikroorganisme. Boyd (1982) menyatakan bahwa kecerahan akibat lumpur sekitar $30 \mathrm{~cm}$ dapat membatasi penetrasi cahaya sehingga tidak dapat menembus kedalaman air dan mengganggu pertumbuhan plankton. Batas kecerahan optimal untuk udang adalah antara $30-40 \mathrm{~cm}$ (Hardjowigeno dan Widiatmaka, 2001). Kecerahan air yang terukur di perairan pantai Pemalang berkisar $36-50 \mathrm{~cm}$ dengan rata rata kecerahan $45,5 \mathrm{~cm}$.

\section{Suhu}

Suhu air merupakan parameter fisik air yang dapat mempengaruhi kehidupan biota perairan karena berkaitan dengan tingkat kelarutan oksigen, proses respirasi biota perairan dan kecepatan degradasi bahan pencemar. Pada umumnya suhu permukaan perairan Indonesia adalah berkisar antara 28 - 31 oC. Suhu air yang terukur di perairan pantai Pemalang masih dalam kisaran yang normal yaitu berkisar antara $28-29^{\circ} \mathrm{C}$. Suhu optimum untuk pertumbuhan udang windu berkisar $29 \mathrm{oC}-31 \mathrm{oC}$ dan untuk udang vaname yaitu 25oC-35oC (PoncePalatox et al., 1997).

Tabel 4. Produksi Udang Vanamei Kabupaten Pemalang tahun 2010 - 2013

\begin{tabular}{|c|c|c|c|c|c|}
\hline NO & KECAMATAN & $\mathbf{2 0 1 0}$ (ton) & $\mathbf{2 0 1 1}$ (ton) & $\mathbf{2 0 1 2}$ (ton) & $\mathbf{2 0 1 3}$ (ton) \\
\hline 1 & PEMALANG & - & - & - & - \\
\hline 2 & T A M A N & - & - & - & - \\
\hline 3 & PETARUKAN & - & - & - & - \\
\hline 4 & ULUJAMI & 21,5 & 1,4 & 11,4 & 73,5 \\
\hline & JUMLAH & 21,5 & 1,4 & 11,4 & 73,5 \\
\hline
\end{tabular}


TSS

Total padatan tersuspensi adalah padatan yang tersuspensi di dalam air berupa bahan-bahan organik dan inorganic yang dapat disaring dengan kertas millipore berporipori $0,45 \mu \mathrm{m}$. Materi yang tersuspensi mempunyai dampak buruk terhadap kualitas air karena mengurangi penetrasi matahari ke dalam badan air, kekeruhan air meningkat yang menyebabkan gangguan pertumbuhan bagi organisme produser. Kandungan total padatan tersuspensi (TSS) yang terukur di perairan pantai Pemalang yaitu sekitar 35 - 424 ppm Perairan yang mempunyai nilai kandungan padatan tersuspensi sebesar 300 - 400 ppm mutu perairan tersebut tergolong buruk (Allert, 1984). Nilai TSS ini berarti berada diambang batas optimal pertumbuhan udang yaitu 80 mg/l oleh karena itu, dalam melakukan kegiatan budidaya udang di wilayah pesisir Pemalang, air laut yang digunakan sebaiknya diendapkan terlebih dahulu di reservoir untuk mengurangi kadar TSS. Padatan tersuspensi $<25 \mathrm{mg} / \mathrm{L}$, baik sebagai media budidaya ikan; 25-80 $\mathrm{mg} / \mathrm{L}$, sedikit berpengaruh sebagai media budidaya ikan; 81-400 mg/L, kurang baik sebagai media budidaya ikan; dan $>400 \mathrm{mg} / \mathrm{L}$, tidak baik sebagai media budidaya ikan (Effendi, 2003).

\section{Parameter Kimia}

$p H$

Air laut memiliki $\mathrm{pH}$ yang relative stabil dan biasanya berkisar antara 7,5 8,4 . Nilai $\mathrm{pH}$ suatu perairan dapat berubah jika perairan tersebut mengalami gangguan seperti pencemaran dan ketidakstabilan lingkungan perairan. Perubahan nilai $\mathrm{pH}$ perairan dapat dipengaruhi oleh beberapa factor diantaranya adalah aktifitas fotosintesis, suhu serta buangan limbah. Nilai pH perairan pesisir Pemalang berkisar antara $7-7,7$. Nilai ini memenuhi syarat untuk budidaya udang.

Tabel 5. Penilaian Kesesuaian Lahan Tambak

\begin{tabular}{|c|l|c|c|c|c|}
\hline No & \multicolumn{1}{|c|}{ Parameter } & Bobot & Nilai & Score & $\begin{array}{c}\text { Nilai } \\
\text { Akhir }\end{array}$ \\
\hline 1 & Salinitas(\%o) & 10 & $20-33$ & 8 & 80 \\
\hline 2 & AmplitudePasang Surut (meter) & 10 & 1,2 & 8 & 80 \\
\hline 3 & $\begin{array}{l}\text { Bentuk Wilayah } \\
\text { (kemiringan lahan) }\end{array}$ & 8 & $0-2 \%$ & 10 & 80 \\
\hline 4 & $\begin{array}{l}\text { Tekstur Tanah } \\
\text { (Material dasar } \\
\text { perairan) }\end{array}$ & 8 & Lempung Berpasir & 8 & 64 \\
\hline 5 & Ketersediaan air tawar (km) & 6 & & & \\
\hline 6 & Fisiografi Wilayah & 6 & Dataran Pasang Surut & 10 & 60 \\
\hline 7 & Jenis vegetasi & 6 & Rhizopora, Avicenia sp. & 8 & 48 \\
\hline & Nilai Total Kategori Kesesuaian Lahan & & & & 448 \\
\hline
\end{tabular}




\section{Salinitas}

Air untuk pengairan tambak udang dapat diperoleh langsung dari laut dengan salinitas antara $30-36 \%$. Udang mampu hidup pada kisaran salinitas antara $15-50 \%$, pada salinitas $<15 \%$ udang dapat tumbuh dengan baik asalkan perubahan salinitas itu tidak terjadi secara mendadak. Walaupun udang mempunyai sifat euryhaline, kisaran salinitas yang baik untuk tambak udang adalah $10-35 \%$ dengan kisaran optimum $15-25 \%$ (Poernomo,1992). Nilai salinitas di perairan pesisir Pemalang berkisar $20-$ $33 \%$ dengan rata- rata salinitas 26,75 $\%$ o. Udang vaname dapat hidup pada kisaran salinitas 1-2 ppt sampai air laut bersalinitas 40 ppt (Menz \& Blake, 1980). Hernandez et al. (2006) menyatakan bahwa pertumbuhan dan sintasan terbaik udang vaname dijumpai pada salinitas 33-40 ppt. Udang windu memiliki toleransi yang tinggi terhadap kisaran salinitas 3-45 ppt dan salinitas optimumnya yaitu 15-25 ppt (Poernomo, 1988).

\section{Oksigen Terlarut}

Oksigen terlarut merupakan salah satu parameter kimia air yang berperan pada kehidupan biota perairan. Penurunan okasigen terlarut dapat mengurangi efisiensi pengambilan oksigen bagi biota perairan sehingga menurunkan kemampuannya untuk hidup normal. Menurut Lung (1993), kelarutan oksigen minimum untuk mendukung kehidupan ikan adalah sekitar 4 ppm. Nilai oksigen terlarut di perairan Pemalang adalah berkisar antara 4,2 - 4,8 ppm. Nilai tersebut masih mendukung kehidupan biota perairan yaitu minimum 4, 0 ppm. Kandungan oksigen terlarut yang mematikan udang vaname adalah $1 \mathrm{mg} / \mathrm{L}$ (Hopkins et al., 1991). Pada saat operasional budidaya tambak, kandungan oksigen terlarut yang kurang dari $2 \mathrm{mg} / \mathrm{L}$ dapat mengakibatkan kematian udang dan batas optimumnya 4-7 mg/L (Poernomo, 1988)

$B O D$

BOD merupakan parameter yang dapat digunakan untuk menggambarkan keberadaan bahan organik di perairan. Hal ini disebabkan BOD dapat menggambarkan jumlah bahan organik yang dapat diuraikan secara biologis, yaitu jumlah oksigen terlarut yang dibutuhkan oleh mikroorganisme untuk memecahkan atau mengoksidasi bahanbahan organik menjadi karbondioksida dan air. Nilai BOD yang tinggi menunjukkan semakin besarnya bahan organik yang terdekomposisi menggunakan sejumlah oksigen di perairan. Adapun nilai BOD di perairan 
Pemalang berkisar antara 3,71 - 10,62 $\mathrm{mg} / \mathrm{l}$, dengan rata-rata $5,7 \mathrm{mg} / \mathrm{l}$. Berdasarkan baku mutu air, nilai BOD yang dipersyaratkan $20 \mathrm{mg} / \mathrm{l}$. Dengan demikian, disimpulkan bahwa perairan Pemalang tidak tercemar oleh bahan organik mudah urai (BOD.

$C O D$

Parameter lain yang juga dapat digunakan sebagai penduga pencemaran limbah organik adalah COD. Nilai COD menggambarkan total oksigen yang dibutuhkan untuk mengoksidasi bahan organik secara kimiawi, baik yang dapat didegradasi secara biologi (biodegradable) maupun yang sukar didegradasi (non biodegradable) menjadi $\mathrm{CO} 2$ dan $\mathrm{H} 2 \mathrm{O}$. Dari hasil analisis kualitas air perairan Pemalang menunjukkan bahwa nilai COD perairan berkisar antara 9,27-26,55 mg/1, dengan nilai rata-rata $14,2 \mathrm{mg} / \mathrm{l}$. Berdasarkan baku mutu air yang mempersyaratkan nilai COD adalah $40 \mathrm{mg} / \mathrm{l}$, maka perairan Pemalang tidak tercemar oleh bahan organik sulit terurai. Nilai COD ini masih berada dalam kisaran baku mutu Iingkungan yaitu $<20 \mathrm{mg} / \mathrm{l}$ (MenKLH 2004). Tingginya kadar COD mencerminkan konsentrasi tinggi senyawa organik di perairan atau penurunan kesehatan ekosistem perairan.
Konsentrasi COD harus di bawah $3 \mathrm{mg} / 1$ di pesisir dan untuk pertambakan.

\section{Ammonia}

Ammonia di perairan dapat berasal dari nitrogen organik dan nitrogen anorganik yang terdapat dalam tanah dan air berasal dari dekomposisi bahan organik oleh mikroba dan jamur. Selain itu, ammonia juga berasal dari denitrifikasi pada dekomposisi limbah oleh mikroba pada kondisi anaerob. Ammonia juga dapat berasal dari limbah domestik dan limbah industri. Hasil analisis kualitas air menunjukkan kadar ammonia di perairan Pemalang berkisar antara $0,06-0,14 \mathrm{mg} / \mathrm{l}$, dengan nilai ratarata adalah 0,09 mg/l. Berdasarkan baku mutu air mensyaratkan kandungan ammonia maksimal $0,3 \mathrm{mg} / \mathrm{l}$. Dengan demikian dapat disimpulkan bahwa perairan Pemalang tidak tercemar ammonia

\section{Phospat}

Fosfat yang terdapat di perairan bersumber dari air buangan penduduk (limbah rumah tangga) berupa deterjen, residu hasil pertanian (pupuk), limbah industri, hancuran bahan organik dan mineral fosfat (Saeni, 1989). Umumnya kandungan fosfat dalam perairan alami sangat kecil dan tidak pernah melampaui $0,1 \mathrm{mg} / \mathrm{l}$, kecuali bila ada penambahan dari luar seperti dari sisa pakan ikan dan 
limbah pertanian . Hasil analisis kualitas air menunjukkan kadar fosfat di perairan Pemalang berkisar antara $0,5-1,0 \mathrm{mg} / 1$, dengan nilai rata-rata $0,58 \mathrm{mg} / \mathrm{l}$.

$\mathrm{NO}_{3}$

Hasil pengukuran kadar nitrat di perairan Pemalang berkisar antara 0,005-0,17 mg/l, dengan nilai rata-rata 0,1075 mg/l. Secara umum, kandungan nitrat perairan Pemalang berada di atas baku mutu air, yang mensyaratkan kandungan nitrat untuk air baku maksimal $10 \mathrm{mg} / \mathrm{l}$. Dengan demikian dapat disimpulkan bahwa perairan Pemalang tercemar oleh senyawa nitrat. Kandungan nitrat dan fosfat air tambak tradisional, sangat diperlukan untuk menstimulir pertumbuhan kelekap, plankton, dan lumut sebagai pakan alami utama bagi ikan dan udang. Kandungan nitrat air laut yang dipersyaratkan untuk kehidupan biota laut yaitu $0,008 \mathrm{mg} / \mathrm{L}$ (KLH, 2004). Kandungan fosfat di perairan alami berkisar 0,005-0,020 mg/L, sedangkan di dalam air tanah biasanya sekitar 0,02 mg/L (Effendi, 2003).

Hasil analisis kualitas air parameter yang sesuai baku mutu adalah kecerahan, suhu, $\mathrm{pH}$, salinitas, DO, BOD, COD dan amonia sedangkan yang melebihi baku mutu adalah paramater TSS, phospat dan nitrat.
Analisis Daya Dukung Kawasan Pesisir untuk Budidaya Udang Vanammei

Analisis daya dukung lingkungan dengan sistem pembobotan adalah salah satu metode yang digunakan dalam analisis daya dukung lingkungan tambak, selain metode analisis regresi polinomial dan metode yang mengacu pada kuantitas perairan (Ratnawati dan Indrajaya 2012). Dalam penelitian ini, pengukuran daya dukung kawasan pesisir dilakukan berdasarkan kualitas perairan dan kuantitas perairan.

\section{. Kuantitas Perairan}

Kuantifikasi atau volume air yang tersedia di pesisir pantai ditentukan oleh volume air laut yang memasuki perairan pantai ketika air pasang. Daya dukung lingkungan untuk kegiatan pertambakan sangat tergantung dari volume air yang tersedia di pantai, dengan asumsi volume air laut yang masuk ke daerah pantai ketika terjadi pasang selalu berganti dari pasang yang satu ke pasang berikutnya, volume air yang berganti itulah yang disebut air yang tersedia di pantai. Karena volume air laut tersebut selalu tergantikan oleh volume air laut dari laut lepas, maka diperkirakan volume air tersebut memiliki kualitas baik untuk kegiatan budidaya 
Kemampuan perairan pesisir dalam mendegradasi limbah terkait dengan proses pencampuran di perairan pesisir yang terjadi antara massa air laut dengan massa air daratan. Proses ini dipengaruhi oleh pasang surut (Tidal Range) yang terjadi di lokasi tersebut. Limbah tambak yang digelontorkan ke laut tidak sepenuhnya terbawa ke laut lepas karena ada sebagian limbah yang tertinggal diperairan pesisir. Pada saat pasang berikutnya limbah yang tertinggal ini akan bercampur dengan limbah tambak yang digelontorkan kemudian.

Pengukuran kuantitas perairan pesisir untuk pertambakan udang bertujuan untuk mengetahui kemampuan perairan pesisir dalam menerima/ mengasimilasi limbah dari kegiatan budidaya udang (Widigdo dan Pariwono 2003). Data yang digunakan untuk menghitung kemampuan perairan pesisir dalam mendegradasi limbah tersebut sebagai berikut :

a. Amplitudo atau kisaran pasang surut (h) $=120 \mathrm{~cm}$ atau 1,2 meter (Dishidros AL. 2013) b. Panjang garis pantai $(\mathrm{y})=35 \mathrm{Km}$ atau 35000 meter ( BPN Kabupaten Pemalang 2013)

c. Jarak dari garis pantai dengan lokasi pengambilan air laut yang kedalamannya \pm 1 meter pada surut terendah $(\mathrm{x})=200$ meter (Hasil pengukuran lapangan)

d. Sudut kemiringan dasar laut kawasan pantai $(\theta)$, rata $1^{\circ}(\mathrm{BPN}$ Kabupaten Pemalang, 2013)

Dari hasil pengumpulan data tersebut kemudian dilakukan penghitungan daya dukung kawasan pesisir untuk pertambakan udang.Hasil penghitungan daya dukung kawasan pesisir Kabupaten Pemalang dapat dilihat pada tabel 6 .

Dimana volume air tersedia sebesar 12.959.998 m3 dan kapasitas limbah yang masih dapat didegradasi atau diasimilasi secara alami sebesar $1 \%$ dari air tersedia atau $129.600 \mathrm{~m} 3$ dan volume tambak maksimal adalah $10 \%$ dari air tersedia atau 1.295.999 m3. Apabila ketinggian air petakan tambak rata - rata 1 meter, maka total luas

\begin{tabular}{|c|c|c|c|c|c|c|c|}
\hline $\begin{array}{l}\text { Sudut } \\
\text { Pantai } \\
(\theta)\end{array}$ & $\begin{array}{l}\text { Panjang } \\
\text { Garis } \\
\text { Pantai } \\
\text { (M) }\end{array}$ & $\begin{array}{c}\text { Volume } \\
\text { Air Pantai / Vo ( } \\
\left.\mathbf{m}^{3}\right)\end{array}$ & $\begin{array}{c}\text { Frekwensi } \\
\text { Pasut / F }\end{array}$ & $\begin{array}{c}\text { Volume Air } \\
\text { Tersedia/ Vs } \\
\left(\mathrm{m}^{3}\right)\end{array}$ & $\begin{array}{c}\text { Volume } \\
\text { Limbah } \\
\text { Maksimal } \\
\left(\mathbf{m}^{3}\right)\end{array}$ & $\begin{array}{c}\text { Volume } \\
\text { Tambak } \\
\text { Maksimal } \\
\left(\mathbf{m}^{3}\right)\end{array}$ & $\begin{array}{c}\text { Luas } \\
\text { Tambak } \\
\text { Maksima } \\
\text { (Ha) }\end{array}$ \\
\hline 1 & 35000 & 6.479 .999 & 2 & 12.959 .998 & 129.600 & 1.295 .999 & 129,6 \\
\hline
\end{tabular}


tambak maksimal adalah 129,6 Ha. Apabila seluruh luas tambak dianggap sebagai tambaksemi intensif, dan dengan asumsi dasar target produksi tambak semi intensif adalah 2 ton/ha/MT, maka total produksi tambak udang maksimal yang masih mungkin dapat diperoleh per musin tanam sebesar 259,2 ton. Dapat dilihat bahwa total luas tambak yang sudah ada (eksisting condition) seluas 1728,31 Ha dan khusus luas tambak udang vanamei baik intensif maupun semi intensif 272,2 $\mathrm{Ha}$ sudah melampaui daya dukung kawasan pesisir Kabupaten Pemalang untuk pengembangan budidaya udang semi intensif secara berkelanjutan atau lestari. Berdasarkan hasil perhittmgan daya dukung kawasan pesisir Kabupaten Pemalang, tambak semi intensif yang dapat dikembangkan sesuai dengan daya dukung lingkungan seluas 129,6 Ha. istilah daya dukung wilayah, yaitu kemampuan wilayah tersebut dalam mempertahankan berbagai pemanfaatan sumberdaya (kegiatan pembangunan) (Clark, 1992 dalam Ratnawati dan Indrajaya 2012). Daya dukung suatu wilayah tidak bersifat statis tetapi dapat menurun akibat kegiatan manusia yang menghasilkan limbah atau kerusakan alam, seperti bencana alam, bahkan dapat ditingkatkan melalui pengelolaan wilayah secara tepat (Clark, 1992dalam

Ratnawati dan Indrajaya 2012 ).

\section{KESIMPULAN DAN SARAN}

\section{Kesimpulan}

1. Berdasarkan perhitungan kesesuaian lahan, nilai total kategori kesesuaian lahan pesisir Kabupaten Pemalang adalah 448 dengan kategori Sesuai (S2) untuk pertambakan

2. Hasil penghitungan daya dukung kawasan pesisir, luas tambak untuk budidaya udang semi intensif yang dapat digunakan diwilayah pesisir Kabupaten Pemalang seluas 129,6 Ha dengan total produksi maksimum sebanyak 259,2 ton / MT

\section{Saran}

Untuk menjaga kelestarian sumberdaya diwilayah pesisir Kabupaten Pemalang dan mencegah terjadinya degradasi kualitas lingkungan maka disarankan untuk tidak menambah luasan tambak semi intensif. .

\section{DAFTAR PUSTAKA}

Ahmad, T., A. Mustafa dan A. Hanafi.1996. Konsep Pengembangan Desa Pantai Mendukung Keberlanjutan Produksi Perikanan Pesisir. Dalam Poernomo, A., H.E. Irianto, S. Nurhakim, Murniyati, dan E. Pratiwi (Eds.). Prosiding Rapat Kerja Teknis Peningkatan Visi Sumberdaya Manusia Peneliti 
Perikanan Menyongsong

Globalisasi IPTEK, Serpong, 19-20 November 1996. Badan

Litbang Pertanian, Puslitbang Perikanan, Jakarta.

Arifin, T., Yulius dan I. S. Arlyza. 2011. Pola Sebaran Spasial dan Karakterisitik Nitrat- FosfatOksigen Terlarut di Perairan Pesisir Makassar. Jurnal Segara, Vol. 7, No.2 : 88-96.

Boyd, C.E. 1982. Water Quality Management For Pond Fish Culture. Elsevier Scienctific Publishing Company. Alabama. USA.318 Pages.

Bengen D.G. 2002. Sinopsis Ekosistem dan Sumberdaya Alam Pesisir. Pusat Kajian Sumberdaya Pesisir dan Lautan (PKSPL).IPB

Dahuri, R.. The Application of Carrying Capacity Concept For Sustainable Coastal Resources Development in Indonesia.. Center For Coastal And Marine Resources Studies Bogor Agricultural University (IPB). www. Pesisir. Or .id. journal carrying capacity. PDF. (Setember 2002)

.Deysandi W, Nursinar S, Faizal K. Kesesuaian Lahan dan Daya Dukung Kawasan Wisata Pantai Botutonuo, Kecamatan Kabila Bone, Kabupaten Bone Bolango. Nikè: Jurnal Ilmiah Perikanan dan Kelautan. Volume 1, Nomor 2, September 2013

Dennis, M., Tammy, T., Baldwin, K., \& Kevin, F. (2004). Aquaculture development potential in Arizona: a GISbased approach. World Aquaculture, 34(4), 32-35.

Effendi, H. (2003). Telaah Kualitas Air Bagi Pengelolaan Sumberdaya dan Lingkungan Perairan. Penerbit Kanisius (Anggota IKAPI), Yogyakarta, $258 \mathrm{hlm}$.

Fredinan Y. Kajian Kesesuaian Dan Daya Dukung Lingkungan Tambak Berbasis Spasial Di Wilayah Pesisir Kabupaten Aceh Utara, Pantai Timur Provinsi Nanggroe Aceh DarusalamJurnal Ilmu-ilmu Perairan dan Perikanan Indonesia, Desember 2008, Jilid 15, Nomor 2: 157-163

Gunggung Senoaji. Daya Dukung Lingkungan Dan Kesesuaian LahanDalam Pengembangan Pulau Enggano Bengkulu. Jurnal Bumi Lestari, Volume 9 No. 2, Agustus 2009, hlm. $159-166$

Hardjowigeno, S.W. 2001. Kesesuaian Lahan dan Perencanaan Tata Guna Tanah. Fakultas Pertanian. IPB.

Hernandez, M.R., Buckle, L.F.R., Palacios, E., \& Baron, B.S. (2006). Preferential behavior of white shrimp Litopenaeus vannamei (Boone, 1931) by progressive temperaturesalinity simultaneous interaction. Journal of Thermal Biology, $31,565-572$.

Hopkins, J.S., Stokes, A.D., Browdy, C.L., \& Sandifer, P.A. (1991). The relationship between feeding rate, padlle 
wheel rate and expected dawn dissolved oxygen in intensive shrimp ponds. Aquacultural Engineering, 10, 281-290.

Ichsan, Mahmudi M, Nuddin H. 2013. Daya Dukung Lingkungan Perairan Berbasis Blue Economy Terhadap Produksi Budidaya Tambak Udang Vanname Di Wilayah Pesisir Probolinggo. Program Pascasarjana Fakultas Perikanan dan Ilmu Kelautan, Universitas Brawijaya

Lung, W.S. 1993. Water Quality Modelling; Application to Estuaria. Vol II CRC Press. Florida.

Menz, A. \& Blake, B.F. (1980). Experiments on the growth of Penaeus vannamei Boone. Journal of Experimental Marine Biology and Ecology, 48, 99-111.

PKSPL, 2002. Kajian Kegiatan Tambak Dalam Hubungannya Dengan Kegiatan Migas dan Lingkungan Hidup di Delta Mahakam. PKSPL - IPB. Bogor

Poernomo, A. (1988). Pembuatan Tambak di Indonesia. Seri Pengembangan No. 7, 1988. Departemen Pertanian, Badan Penelitian dan Pengembangan Pertanian, Balai Penelitian Perikanan Budidaya Pantai, Maros, 30 hlm.

Poernomo, 1992. Pemilihan Lokasi Tambak Udang Berwawasan Lingkungan. Pusat Penelitian dan Pengembangan Perikanan Badan Penelitian dan
Pengembangan Pertanian. Jakarta

Ponce-Palatox, J., Martinez-Palacios, C.A., \& Ross. L.G. (1997). The effect of salinity and temperature on the growth and survival rates of juvenile white shrimp, Penaeus vannamei, Boone, 1931. Aquaculture, 157, 107-115.

Prasita VD, Widigdo B, S. Hardjowigeno, S. Budiharsono S. Kajian Daya Dukung Lingkungan Kawasan Pertambakan Di Pantura Kabupaten Gresik Jawa TimurJurnal Ilmu-ilmu Perairan dan Perikanan Indonesia, Desember 2008, Jilid 15, Nomor 2: 95-102

Ratnawati E, Indrajaya A. Daya Dukung Lingkungan Tambak Di Kecamatan Pulau Derawan Dan Sambaliung, Kabupaten Berau, Provinsi Kalimantan Timur. Jurnal Ilmiah Perikanan dan Kelautan Vol. 4 No. 2, November 2012

Ristiyani D. 2012. Evaluasi kesesuaian Lahan untuk Budidaya Perikanan Tambak di Pesisir Kendal. Geo Image 1 (1) (2012)

Senoaji G. 2009. Daya Dukung Lingkungan Dan Kesesuaian LahanDalam Pengembangan Pulau Enggano Bengkulu. Jurnal Bumi Lestari, Volume 9 No. 2, Agustus 2009, hlm. $159-166$

Utojo, Arifuddin T, Rezki A. S. 2013. Kesesuaian Lahan dan Revitalisasi Tambak Budidaya Udang Di Kawasan Industrialisasi Kabupaten 
Probolinggo Provinsi Jawa

Timur. J. Ris. Akuakultur

Vol. 9 No. 3 Tahun 2014:

501-513

Widigdo B dan Kadarwan Soewardi. 2002. Rumusan Kriteria EkoBiologis dalam Menentukan Potensi Alami Kawasan Pesisir untuk Budidaya Tambak. Diktat Bahan Kuliah Pengembangan Perikanan Kawasan Pesisir dan Laut. Institut Pertanian Bogor. Bogor. 32 hal.

Widigdo, B., dan J. Pariwono, 2003. Daya Dukung Perairan di Pantai Utara Jawa Barat untuk Budidaya Udang (Studi Kasus di Kabupaten Subang, Teluk Jakarta dan Serang), Jurnal Ilmu-ilmu Perairan danPerikanan Indonesia, 1: 10-17. 